\title{
Beneficial and Interfering Beliefs About Learning English
}

\author{
Sakae Suzuki \\ Shonan Institute of Technology, Fujisawa, Japan
}

\begin{abstract}
This longitudinal study was designed to provide an orderly account of how beliefs about English language learning develop among seven Japanese high school students identifying beliefs that are beneficial and interfering for language learning and the routes by which these beliefs are reached. The data for the study were collected from seven students attending a Japanese public high school. Beginning when the students were first-year high school students (10th graders), the data, which were drawn from in-depth interviews, journals, written reports, observations, and school records, form a qualitative multiple-case-study. Data gathering ended when the students chose a university in the third year of high school. Beneficial beliefs enhance learners' motivation to learn, while interfering beliefs concern negative thoughts that hinder them from learning and from engaging in challenging tasks. Those beliefs are context-sensitive; thus, they are not necessarily shared by all learners. Individual learners have different beneficial and interfering beliefs depending on their learning context. This study found that learners developed personal theories about learning based on their beliefs. Considering that learners behave according to their theories of learning, eliciting learners' beliefs can bring benefits for researchers and teachers because they can anticipate learners' behavior by knowing their beliefs.
\end{abstract}

Keywords: learners beliefs, self-efficacy, beneficial beliefs, interfering beliefs

\section{Introduction}

Horwitz's study (1987) on learners' beliefs had a ripple effect in the field of foreign language education. A considerable body of research on learners' beliefs followed (e.g., Campbell, Shaw, Plageman, \& Allen, 1993; Cotterall, 1995; Kuntz, 1996; Sakui \& Gaies, 1999; Yang, 1992; Wenden, 1987). Those researches used the BALLI (the Beliefs about Language Learning Inventory) or a modified version of the BALLI and elicited learners' beliefs in cross-sectional studies (Bernat \& Gvozdenko, 2005). Those studies in which a questionnaire was used were referred to as the "mainstream" approach (Kalaja, 2006) in which an etic (outsider perspective) research method was applied (Bernat \& Gvozdenko, 2005) thus, learners' beliefs were elicited from the perspective of teaching (Woods, 1996), or trying to build an architecture of a stable belief system (Kramsch, 2006).

Those studies, however, did not shed light on the construction of learners' beliefs, where their beliefs come from, what effect the beliefs have on the learning process, their functions, or the ways in which they are open to change (Benson \& Lior, 1999). These questionnaire studies were not designed to investigate how learners develop positive and negative beliefs about learning English, how they develop beliefs that enhance their ability

Sakae Suzuki, professor, Ed.D., Center for Liberal Arts, Shonan Institute of Technology. 
to sustain learning English, and how their beliefs help them make decisions to carry out actions related to language learning and find the meaning of learning English, and what factors influence developing positive and negative attitudes toward learning English. A questionnaire response cannot be interpreted as a long-term personal trait, but only as a memory reaction based on the stimulus and the respondent's age and experiences to date. The complex nature of learners' beliefs is illustrated by their defining characteristics: They are dynamic and emergent, socially constructed, contextually situated, experiential, mediated, and paradoxical and contradictory (Kalaja, 2006) and they have not been investigated sufficiently.

\section{The EFL Situation in Japan}

English has achieved the status of world language and it is used as the official language and the second language in many countries. In Japan, English has long been considered an important tool for business and communication. English has both officially and privately been perceived as an important subject at schools or for personal development. English is, however, neither the official nor the second language in Japan.

People in Japan can live without using English. They can buy food in Japanese, work using Japanese, and communicate with their peers or colleagues in Japanese as long as they work and live in a Japanese community. Even though many Japanese realize that English can broaden their views and give them chances to communicate with people around the world, they do not feel that English is a necessary survival tool. Many students, even though they study English at school, do not often use English outside of school. Thus, learners of English in Japan usually do not have "social practices in a context in which individual learner L2s develop" (Norton \& Toohey, 2001, p. 318). They often do not study unless they have to take exams in English or they expect to go overseas for sightseeing, study, or work. As Yashima, Nishide, and Shimizu (2004) notified,

many Japanese adolescents, preoccupied with preparing for entrance exams to higher education, concentrate on raising test scores by memorizing vocabulary, idiomatic expressions and practicing sentence translation. These activities are of some value for improving L2 proficiency, but under these circumstances, communicating with people in the world as a goal of EFL may seem somewhat unrealistic. (p. 121)

\section{Theoretical Framework}

Self-efficacy is a belief that one has the ability to complete actions and tasks that are required in prospective situations. Bandura (1978) defined self-efficacy as "a judgment of one's ability to execute a particular behavior pattern" (p. 240). Self-efficacy affects human functions such as choices, motivation, attribution, and control of their own lives. Self-efficacy judgments also determine how much effort people will spend on a task and how long they will persist with it. People with strong self-efficacy beliefs exert greater efforts to master a challenge while those with weak self-efficacy beliefs are likely to reduce their efforts or even quit. Bandura's notion of self-efficacy explains beneficial beliefs, and interfering beliefs in this study. People who hold a high self-efficacy have a high motivation, take risks, and are eager to learn. On the other hand, people who hold a low self-efficacy tend to avoid challenge. This dual explanation of high and low self-efficacy was followed by Dweck (2006)'s explanation of two mindsets. Dweck (2006) discerned two types of mindsets regarding self-efficacy: She termed them as a growth mindset and a fixed mindset. The growth mindset is "based on the belief that your basic qualities are things you can cultivate through your efforts" (Dweck, 2006, p. 7) and the fixed mindset "focuses on permanent traits and leads people to fear challenge and devalue effort" (p. 10). 
Through research, she found that people with the growth mindset were not labeling themselves and not giving up and that people with the fixed mindset did not believe in their capacity for growth. She claimed that "mindsets are just beliefs and you can change your mind" (Dweck, 2006, p. 16).

Self-efficacy theory according to Bandura (1977) proposed that there are four major sources of information used by individuals when forming self-efficacy judgments. The first is performance accomplishments, i.e., personal assessment of an individual's personal mastery or accomplishments (past experiences with the specific task being successfully accomplished). Previous successes raise mastery expectations, while repeated failures lower them. The second source is vicarious experience, which is gained by observing others perform activities successfully. This is often referred to as modeling, and it can generate expectations in observers that they can improve their own performance by emulating what they have observed (Bandura, 1977). The third source is social persuasion, which refers to activities where people are led, through suggestion, into believing that they can cope successfully with specific tasks. Coaching and giving evaluative feedback on performance are common types of social persuasion (Bandura, 1977). The final source of information is physiological and emotional states. The individual's physiological or emotional states influence self-efficacy judgments with respect to specific tasks. Emotional reactions to such tasks (e.g., anxiety) can lead to negative judgments of one's ability to complete the tasks (Bandura, 1988). Bandura (1982) concluded that self-efficacy theory had considerable explanatory power. His review found that perceived self-efficacy helped to account for a wide variety of individual behaviors, including changes in coping behavior produced by different modes of influence, levels of physiological stress reactions, self-regulation, achievement strivings, and choice of career pursuits.

\section{Method}

\section{Multiple Case Studies}

A case study is an exploration of a "bounded system" or multiple cases over time through detailed, in-depth data collection involving multiple sources of rich information in a context (Creswell, 1998). Thus, multiple-case studies involve collecting and analyzing data from two or more cases within the same study. The bounded system is bounded by time and place and it is the case studied (Creswell, 1998). In this study, the bounded system is a public Japanese high school and cases are individual students. Yin (2003) indicated that multiple cases should be selected so that they replicate each other by either predicting similar results or contrasting results for predictable reasons. In this study, the seven participants had the desire to study English in the beginning of the investigation. Some of them might follow a similar process of learning and others might not.

\section{Research Site}

The research site, Rokkaku High School (pseudonym) is located in Yokohama, a major port city close to Tokyo, in Japan. The school was founded 16 years ago as an experimental and pioneer school with a credit system for classes which gave students more choices than usual choice of classes. The school policy has been to accept a variety of students: regular students who graduated from Japanese junior high schools, returnees who lived abroad, foreign students living in Japan, and restarters who quit other high schools. 


\section{Participants}

There are seven participants in this study. One of the students entered Rokkaku high school as first-year students in 2005, five of them entered Rokkaku High School in April, 2006, and one entered as a second-year student in September, 2006 after quitting another private high school. The first-year students were chosen in order to investigate their English learning history before high school. The second-year student was included in order to observe how studying for entrance examination (juken-style learning), which emphasizes rote memorization, influences her beliefs.

Table 1 summarizes the backgrounds of the seven participants.

Table 1

Study Participants

\begin{tabular}{|c|c|c|c|}
\hline Name & Gender & Country of origin & Remarks \\
\hline Maiko & Female & Canada & $\begin{array}{l}\text { - Spent a few years overseas } \\
\text { - High proficiency of English }\end{array}$ \\
\hline Satsuki & Female & Japan & - Extensive overseas experience \\
\hline Kazuo & Male & Peru & $\begin{array}{l}\text { - Came to Japan at the age of } 15 \\
\text { - Went to a Japanese school in Peru }\end{array}$ \\
\hline Fumi & Female & Japan & $\begin{array}{l}\text { - Likes playing the guitar and reading } \\
\text { - Passed the entrance examination at Sophia University }\end{array}$ \\
\hline Honey & Female & Myanmar & $\begin{array}{l}\text { - Came to Japan at the age of } 15 \text {. } \\
\text { - Wanted to be a doctor, now wants to be a radiologist }\end{array}$ \\
\hline Rumiko & Female & Japan & $\begin{array}{l}\text {-Wants to be an English teacher } \\
\text { - Was inspired by a cram school teacher }\end{array}$ \\
\hline Natsuko & Female & Japan & $\begin{array}{l}\text { - Quit a high school and entered Rokkaku High School } \\
\text { - Went to the Philippines to study English } \\
\text { - Decided to go to a university in Okinawa }\end{array}$ \\
\hline
\end{tabular}

\section{Data Analysis}

Data analysis took place both during and after data collection from 2006 to 2009, in line with Creswell's (1998) emphasis on a zigzag approach between data gathering and analysis. Interpretation of interview data was presented to the participants immediately after the first interview (Kanno, 2003). Each time I met a participant; I went over the previous data and discussed possible interpretations.

I made a matrix of beliefs with two kinds: beneficial beliefs, and interfering beliefs. Beneficial beliefs are positive beliefs that lead to the participants active learning. Interfering beliefs are negative beliefs that interfere the participants' learning. Those two types of beliefs are put into a word table. Cross-case analysis of beliefs was conducted based on this word table.

\section{Research Questions}

(1) What learners' beliefs are beneficial for language learning, and what beliefs hinder language learning of high school students?

(2) What factors contribute to learners' developing beliefs?

\section{Results and Discussion}

\section{Research Question 1: Beneficial Beliefs and Interfering Beliefs}

Beneficial beliefs. Learners' beliefs can be beneficial if they lead to awareness of learning strategies for 
further learning and are therefore facilitative of learning (Bernat \& Gvozdenko, 2005). In the present study, for example, Kazuo, who believed that speaking English had highest priority, developed a new belief that studying grammar and vocabulary was necessary for him. This new belief led him to take actions that made his learning more efficient.

There can never be an absolute list of beneficial beliefs because people and situations are different from each other and complex. In the present study, however, ten beliefs emerged as effective in helping the participants develop learning strategies and sustain deep learning. Those beliefs can be general beneficial beliefs that young learners might develop in their adolescence. The findings were:

(1) Learners develop the belief that speaking English is fun through experiences of making themselves understood in English. This belief is a springboard for them to seek opportunities to speak English.

(2) Natsuko, Kazuo, Satsuki, and Maiko's stories suggest that firsthand experiences of meeting foreign people and cultures impact learners, helping them cultivate beliefs that meeting foreign people and knowing their cultures is interesting.

(3) When young learners in the present study were put into context where their first language was not acceptable, they struggled to acquire language skills needed in order to survive in the context. It is not an easy task for those learners: They experience uneasiness, anxiety, and conflict. Among seven participants, Maiko spent her pre-school days in Canada, Honey was sent to an international school when she was ten and Kazuo lived in Peru for 15 years. All of them had their "language home" where they can communicate with their first language but outside the home they struggled with languages: Maiko in a local preschool in Canada, Honey in an international school in Myanmar, and Kazuo in a private juku in Peru. For those who experienced language struggle, they developed a belief that English is a tool for communication.

(4) A belief that change is helpful, for example, changing schools or changing goals, is a beneficial belief for young learners when they face difficulties and constraints from the authority. Tolerance helps some learners but others need change. This is because in many cases, especially with young learners, the learning context is chosen by their parents and not themselves. Their choices, based on the necessary cultural and economic capital (Bourdieu, 1977) to select their children's education from a range of options, thus, "had a strong impact on their children's language and identity" (Okada, pp. 247-249). As Natsuko's case implied, physical and emotional pain of learners that is caused by a mismatch between school and learner is a signal for changing context. Natsuko wrote:

In the seond year at Sakura High School, I spent a lot of time on dancing. Then, I became reluctant to go to school. Teachers told me things; I hated school rules, and eventually going to school became a big stress for me. (see Appendix A, Questionnaire-5, 2008)

Natsuko was happy at her new school, Rokkaku High School, where she was not forced by teachers to study hard to get into a big-name university.

(5) As Natsuko and Kazuo judged their own English ability, a belief about themselves that they have correctable deficiencies was a beneficial one that encouraged them to study more. At first, Kazuo did not believe that grammar was important to speak English. Thus, he did not listen to a teacher at a junior high school in Peru saying that he had to pay more attention to spelling and grammar. In high school, however, he demonstrated a 
reevaluated belief that he needed grammatical knowledge to become a better speaker. Natsuko, too, said that at her second high school she needed to change her study style to entrance-examination-style to develop vocabulary and grammatical knowledge to understand complicated English. Their reflection on their specific learning deficiencies helped them concentrate on their studies.

(6) While Kazuo and Natsuko, being aware of their insufficient English, had the intention of being better learners, Maiko believed that she should not be satisfied with her English: She had the ambition to be a master of English. Those intention or ambition led to positive attitude considering further study as being rewarded.

(7) The belief that English is interesting is a beneficial thought. Two of the learners who were born in foreign countries, Kazuo and Maiko, and two who traveled to foreign countries when they were young, Natsuko and Satsuki, believed that English was interesting. They were put into contexts of knowing and learning English, where they developed interest in English. Fumiko's interest in English was cultivated by her father who introduced English music to her. Honey was born in Myanmar and put into an international school by her father. Rumiko, who had never been abroad, first became interested in English because of an English poster that her mother posted in the toilet. The seven learners' encounters with English differ, but as their stories show, they all have interest in common.

(8) A belief that English is a lifesaver or an ancarage was shared by Fumiko, who was bullied in junior high school and Honey, who was brought to Japan by her father. Both learners had constraints and difficulties in their daily lives, and English helped them escape from difficulties and keep going forward. Fumiko explained that she survived hardships by studying, and especially studying English, which she liked most. No one suggested that she studied English to get over bullying but she found the process by herself. Thus, for Fumiko, English was a life saver or an anchorage that helped her become confident. A foreign student living in Japan has to compete academically with Japanese students in school. Not having grown up in Japan, they need to improve their Japanese language ability in order to keep up with, and compete with, Japanese students. Developing an appropriate ability takes time. A student like Honey, however, who knew English well before coming to Japan, can use English as a weapon to compete with Japanese students. Honey thought of her English as a competitive weapon. She became confident after learning English because she felt that she had gained power.

(9) A belief that one does not accept defeat seemed to be beneficial for some learners as it drove them to study hard. Maiko and Natsuko described this belief as part of their personalities. A belief that one does not accept defeat works as a beneficial belief when there are chances or experiences to develop affordances and make the effort beneficial. Commitment and passion lead to success in helping learners make use of experiences and affordances. Maiko's narratives explained her unyielding feature. She wrote that, "in the fifth grade of an elementary school, I began to want to get $100 \%$ on tests" (see Appendix A, Questionnaire-5). In high school, she joined the English Day Camp where students were required to discuss issues in English. At that point, she wrote:

When I could not make myself understood in English during discussion, I felt ashamed and thought many times that I had to put more efforts (Journal-1, 2006).

(10) The belief that a fluent speaker of English is cool is beneficial when it helps the learner make efforts to develop his or her speaking skill. A questionnaire study (Suzuki, 2006) indicated that high school students think that someone who speaks English is cool. They admire people who speak English fluently with native-like pronunciation, perhaps because speaking is the most obvious of the four skills of English; speaking, listening, 
reading, and writing.

To sum up, Beneficial beliefs of adolescents in this study are statements about reality including the nature of the world, the nature of oneself, and the relation between the two. Common features may be summarized as follows. They seem to have several common features.

First, curiosity and interest toward foreign cultures and people bring about beneficial beliefs and they lead to learners' active participation in foreign communities and learning opportunities. In this way, beneficial beliefs lead to active learning.

Second, confidence about English ability leads to beneficial beliefs concerning a learner's ability to control his or her progress, thus supporting learners' sense of self-efficacy and helping them make their own decisions.

Third, beneficial beliefs have a reflective nature. When learners review their attitudes and actions, they develop beneficial beliefs that lead to forward movement.

Fourth, for adolescents, part of their growth is developing a sense of agency that encourages them to make their own decisions. Thus, one type of beneficial belief is a belief that they can make their own choices of schools and of learning strategies.

Interfering beliefs. Interfering beliefs include learners' negative feelings such as hatred, rejection, stress, and anger that hinder learners from learning. Learners can have "mistaken", uninformed, or negative beliefs that may lead to ineffective strategies, a negative attitude towards learning and autonomy (Bernat \& Gvozdenko, 2005), and avoidance. Natsuko's negative belief that studying for entrance examinations causes stress emerged in her experiences of studying for entrance examinations. Her negative belief about studying for entrance examinations became embedded, and made her reject any study of that kind. Perhaps, interfering beliefs, or inhibitive beliefs (Bernat \& Gvozdenko, 2005) generate negative thinking that causes further interfering beliefs. In the present study, five interfering beliefs were identified. The findings were:

(1) Beliefs about potentiality that are based on attribution to social or environmental factors hinder learners' active participation in learning, as Rumiko's case shows: She believed that her poor speaking ability of English, is due to English education in Japan and her lack of overseas experience. This belief interfered with Rumiko's motivation to learn English.

(2) This study also showed that many students had a belief that being good at English means getting good grades on English tests. Rumiko, Satsuki, Maiko, and Kazuo all held this belief before they came to Rokkaku High School. Their grades in junior high school were good enough for them to describe themselves as being good at English. In high school, however, they found that the status of being good at English was not easily attained because there were many students who were excellent in English.

(3) Beliefs with low self-efficacy are interfering beliefs. Some of participants of this study talked about their belief that they would never be as fluent as returnee students; they feel intimidated by them. This feelling of inferiority brings interfering beliefs that they were ashamed of their pronunciation, and that they should not speak English in front of returnee students. Those beliefs interfere learners to expose themselves in English, which leads to demotivation to study English.

(4) Students who have never lived in English-speaking countries tend to believe that living there will make them fluent speakers of English. This is a common belief among language learners and educators (Tanaka \& Ellis, 2003). This second-hand belief is interfering when it invites excuses for learners; they can not speak English 
because they have never lived in English-speaking countries, or studying English in Japan will not make them fluent speakers of English. Rumiko and Satsuki postponed their efforts to develop speaking ability; they said that at university they would go abroad and study.

(5) Kazuo, Natsuko, and Rumiko believed that being good at English meant being good at speaking English. This belief hindered them from being fully engaged in learning in classrooms focusing on grammar or test-taking. Peacock (1999) studied learners in Hong Kong and found that $62 \%$ of participants believed that learning a foreign language was mostly a matter of learning a lot of grammar rules and concluded that learners had an "incorrect" belief about learning a foreign language and that this incorrect belief could cause dissatisfaction among learners if teachers emphasize communicative tasks rather than grammatical practices.

To sum up, Interfering beliefs of adolescents in this study were students' interpretations of the relation between themselves and their environments that caused them not to devote effort to improve their English or to do so in an inefficient way. Interfering beliefs seem to have three characteristics.

First, interfering beliefs are related to loss of confidence, in which students believe that they are not able to achieve what they want.

Second, interfering beliefs seem to be the result of fixed mindsets or stereotypical thoughts. Thus Rumiko believed that she would never speak good English without going overseas. Such beliefs often allow learners an excuse not to make effort. When students depend on fixed ideas and stereotypical thoughts, they limit their choices in a less than optimum way.

Third, overdependence on the opinions of others causes interfering beliefs. For adolescents, failure to think the facts through or to organize their options rationally leave students at the mercy of the opinions of others or of half-baked ideas of their own.

\section{Research Question 2: What Factors Contribute to Learners' Developing Beliefs?}

Beneficial beliefs. As my data suggested above, beneficial beliefs are stimuli for learners to develop motivation to learn and challenge new tasks. I draw Bandura's (1993) concept of self-efficacy and Dweck's (2006) arguments about a growth mindset that explains how people develop self-efficacy to challenge and that argues influences of self-efficacy on beneficial beliefs. I will discuss how self-efficacy in the literature applies to my data and consequences of self-efficacy on participants of this study so that I can add new perspectives toward self-efficacy of learners in Japanese context.

Bandura points to four sources affecting self-efficacy; performance accomplishments, vicarious experience, verbal persuasion, and emotional arousal. I will discuss performance accomplishments and vicarious experience as it applies to my data.

First, performance accomplishment "mastery experience" is the most important factor deciding a person's self-efficacy. In other words, success raises self-efficacy; failure lowers it. Empirical evidence is found on my data. Kazuo's chance-encounter-experience talking in English with a Korean lady that was repeated several times during interviews was a mastery experience for him. Through the experience he had a feeling that he "made it in English", which developed a belief that learning English is for communication. In Japan, passing the entrance exam is very important and successful occurrence for students. Thus, passing a competitive entrance exam is considered to be a big success. This social norm in Japan influences students' self-efficacy. I, suggest passing 
exams can be a mastery experience for some students in Japanese context.

Second, vicarious experience explains that "seeing others' perform threatening activities without adverse consequences can create expectations in observers that they too will eventually succeed if they intensify and persist in their efforts" (Banruda, 1977, p. 81). Maiko's story is evidence of this; she observed older students' performances and learned their positive attitudes, and those inspired her to become an active learner. She was in her older students' group and worked together, thus, a theory of vicarious experience worked. However, as Rumiko's story suggests that if others' performance is considerably overwhelming to a person, he or she might not be encouraged but lose confidence. Rumiko felt that she could not compete with returnees who lived in English-speaking countries. She did not belong to their group. Maiko and Rumiko's stories suggest that a theory of vicarious experience works when a person is involved with those who perform well, otherwise, he or she might feel intimidated.

Next, I will write how a growth mindset that Dwerck claims above is observed among participants of this study and how it affects beliefs by drawing my data. Also, Dweck did not describe what helped people to develop two mindsets, thus, I drew data from this study indicating what helped some of participants of this study to develop a growth mindset.

Maiko has a growth mindset. She considers learning important and wants to take chances to do so, for her, "adolescence is a time of opportunity; a time to learn new subjects, a time to find out what they like and what they want to become in the future" (Dweck, 2006, p. 59). She was influenced by her senior students who always challenged and developed a belief that she should not be satisfied with her English. Natsuko was able to take charge of her learning and setting a goal for her. She did not have a belief that "other people can define them" (Dweck, 2006, p. 80). When she decided to go to a small university in Okinawa, her friends told her to try to get in a prestigious university. Perhaps, they had a fixed mindset that going to a prestigious university leads to a successful life. Natsuko was not influenced by them, instead, she confirmed herself that she knew what she wanted to do at a university. She believed that what she wanted to do is the best thing. This belief was developed in her experience of joining a dance club and observed people who enjoyed what they were doing. Natsuko, therefore, holds a high control belief (Flammer, 1995) which leads to a positive outlook on their future and raises the chances of change and development. A person with a growth mindset opens a door to a new learning opportunity. Kazuo used to have a fixed mindset believing that grammar was not important for speaking English at junior high school, thus, he did not listen to teachers who corrected his grammatical mistakes. At high school, though, through experiences to talk in English with speakers of English, he became to realize that learning grammar was important to develop his speaking skill in English. He learned from his first-hand experiences. Fumi and Honey developed their self-efficacy because of English, cultural capital (Bourdieu, 1991). Being good at English receives appraisals in Japan in context such as schools, media, work, and even in public. Honey depended her self-efficacy on her English speaking ability she gained in an international school in Myanmar. Fumi was saved by English when she faced difficulties in being self in junior high school because she was bullied by her classmates. Adolescents are in the process of finding "self", thus they are often fragile when facing a crisis of losing their self, an identity. In a case of Honey, a person from a foreign country, a social weapon such as English ability, helps to develop self-efficacy. Also, as Fumiko's case identified, an adolescent with a swinging identity, perhaps, needs a social weapon to defend them. 
Interfering beliefs. In literature, as Bandura (1977) suggested, a person with low self-efficacy developed feelings of hopelessness and avoided tasks. Dweck (2006)'s claim of a fixed mindset explains interfering beliefs and consequences of holding it. For people with a fixed mindset, everything is the outcome. Thus, if they fail, they will be a failure all the time. Dweck (2006) reported that students with the fixed mindset had higher levels of depression (p. 38) because they are always in danger of being measured by a failure (p. 39); they are filled with limiting thoughts and eventually, they develop negative stereotypes (p. 75).

I wrote about my observations of a fixed mindset in my data that led or might lead to a low self-efficacy. Rumiko, a student who has never been abroad, developed a fixed mindset believing that she would not be able to speak English well without going abroad. The source of this belief was her observations of returnees who lived in English speaking countries for a while and speak English fluently. Being with them caused her to develop another stereotypical fixed mindset, a belief, that native-like pronunciation of English is important. Rumiko's negative feelings about herself, lack of oversea experience and bad English pronunciation, may be shared among many learners of English in Japan. Because of low evaluation of her English-speaking ability, Rumiko avoided taking part in English classes and activities to speak English. Rumiko's self-efficacy about her speaking ability of English was low. Students have a low self efficacy when they attribute failure to deficient ability (Zimmerman, 1995) as Rumiko repeatedly talked about her insufficient ability of speaking English.

\section{Conclusion}

I conclude this study by referring to four findings.

First, Barcelos (2006) suggested that beliefs exist within one's experiences, and the results of this study supported her claim empirically. As data of this study showed, learners are influenced by learning experiences and modified their beliefs accordingly.

Second, I found that some beliefs are reflective and retrospective. This is because learners develop beliefs in the process of thinking or doing actions and beliefs that are shaped within experiences are contextual and personal. Learners are not always aware of their beliefs. Those are elicited by means of stories for the researcher.

Third, I found two categories each belief can fit in with: beneficial beliefs, and interfering beliefs among emerged beliefs of learners.

Fourth, learners develop their personal theories within which beliefs are included. I found that individual differences of learner's beliefs can be explained by a dynamic systems on developmental psychology which infers that different children will follow subtly different paths, even they all end up at the same milestones: Each learner takes different path even he or she goes to the same final destination.

\section{References}

Bandura, A. (1977). Self-efficacy: Toward a unifying theory of behavior change. Psychological Reivew, 84, 191-215.

Bandura, A. (1978). Reflections on self-efficacy. Advances in Behavioral Research and Therapy, 1(4), 237-269.

Bandura, A. (1988). Perceived self-efficacy: Exercise of control through self-belief. In J. P. Dauwalder, M. Perrez, \& V. Hobi (Eds.), Annual series of European research in behavior therapy (Vol. 2, pp. 27-59). Amsterdam/ Lisse: ZSwets \& Zeitlinger.

Bandura, A. (1993). Perceived self-efficacy in cognitive development and functioning. Educational Psychologist, $28,117-148$.

Benson, P., \& Lior, W. (1999). Conceptions of language and language learning. System, 27, 459-472.

Bernat, E., \& Gvozdenko, I. (2005). Beliefs about language learning: Current knowledge, pedagogical implications, and new research directions. TESL-EJ, 9, 1-27. 
Bourdieu, P. (1991). Language and symbolic power. In J. B. Thompson, Ed.; G. Raymond \& M. Adamson, Trans. Oxford: Polity Press.

Boudieu, P. (1977). The economics of linguistic exchange. Social Science Information, 16(6), 645-668.

Campbell, C. M., Shaw, V. M., Plageman, M. E., \& Allen, T. A. (1993). Exploring student beliefs about language learning. In W. N. $\mathrm{H}$. Hatfield (Ed.), Visions and realities in foreign language teaching: Where we are, where we are going (pp. 29-39). Lincolnwood, IL: National Textbook.

Cotterall, S. (1995). Readiness for autonomy: Investigating learner beliefs. System, 23, 195-205.

Creswell, J. W. (1998). Qualitative inquiry and research design. Thousand Oaks, CA: Sage.

Dweck, C. S. (2006). Mindset. New York: Ballantime books.

Flammer, A. (1995). Development analysis of control beliefs. In A. Bandura (Ed.), Self-efficacy in changing societies (pp. 69-113). Cambridge: Cambridge University Press.

Horwitz, E. K. (1987). Surveying student beliefs about language learning. In A. Wenden \& J. Rubin (Eds.), Learning strategies in language learning. Englewood Cliffs, NJ: Prentice-Hall.

Kalaja, P. (2006). Research on students' beliefs about SLA within a discursive approach. In P. Kalaja \& A. M. F. Barcelos (Eds.), Beliefs about SLA: New research approaches (pp. 87-108). Dordrecht: Kluwer.

Kanno, Y. (2003). Negotiating bilingual and bicultural identities. Mahwah, NJ: Erlbaum.

Kramsch, C. (2006). Metaphor and the subjective construction of beliefs. In P. Kalaja \& A. M. F. Barcelos (Eds.), Beliefs about SLA: New research approaches (pp. 109-128). Dordrecht: Kluwer.

Kuntz, R. G. (1996). Students of “easy” languages: Their beliefs about language learning. (ERIC Document Reproduction Service No. ED397658)

Norton, B., \& Toohey, K. (2001). Changing perspectives on good language learners. TESOL Quarterly, 35, 307-322.

Okada, H. (2009). Somewhere "in between": Languages and identities of three Japanse international school students (Unpublished Ed.D. thesis, the Temple University, Japan).

Peacock, M. (1999). Beliefs about language learning and their relationship to proficiency. International Journal of Applied Linguistics, 9(2), 247-265.

Sakui, K., \& Gaies, S. J. (1999). Investigating Japanese learners' beliefs about language learning. System, 27, 473-492.

Suzuki, S. (2006). A study of Japanese high school students beliefs about learning English. Eigo Kyoiku Kenkyu (English Education Study), 42,10-21.

Tanaka, K., \& Ellis, R. (2003). Study-abroad, language proficiency, and learner beliefs about language learning. JALT Journal, 25 (1), 63-85.

Wenden, A. (1987). How to be a successful language learner. In A. Wenden \& J. Rubin (Eds.), Learner strategies in language learning (pp. 103-117). London:Prentice Hall.

Woods, D. (1996). Teacher cognition in language teaching: Beliefs, decision-making and classroom practice. Cambridge: Cambridge University Press.

Yang, N. D. (1992). Second language learners' beliefs about language learning and their use of learning strategies: A study of college students of English in Taiwan (Unpublished doctoral dissertation, the University of Texas at Austin, Texas).

Yashima, T., Nishide, L., \& Shimizu, K. (2004). The influence of attitudes and affect on willingness to communicate and second language communication. Language Learning, 54(1), 119-152.

Yin, R. K. (2003). Case study research: Design and methods (3rd ed.). Thousand Oaks, CA: Sage.

Zimmerman, B. J. (1995). Self-efficacy and educational development. In A. Bandura (Ed.), Self-efficacy in changing societies (pp. 202-231). New York: Cambridge University Press.

\section{Appendix A: Questionnaire (English version)}

Rokkaku High School, Foreign Language Department

Sakae Suzuki

\begin{tabular}{|c|c|c|c|c|c|}
\hline 1. & \begin{tabular}{|l|} 
Student number: \\
Koseika Course $•$ Interna \\
\end{tabular} & $\begin{array}{c}\text { Name: } \\
\text { ational Understan } \\
\end{array}$ & \multicolumn{2}{|c|}{ Koseika Course $\cdot$ International Understanding Course (Circle one and write reasons why you chose the course) } & e course) \\
\hline 2. & Birth Place: Kanagawa ( & ) city & Others: & & \\
\hline 3. & $\begin{array}{l}\text { Overseas experience: ( } \\
\text { School: Local school }\end{array}$ & $\begin{array}{c}\text { ) years } \\
\text { Japanese school }\end{array}$ & $\begin{array}{l}\text { Place ( } \\
\text { Others ( }\end{array}$ & 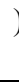 & ) \\
\hline
\end{tabular}




\begin{tabular}{|c|c|c|}
\hline 4. & $\begin{array}{l}\text { Elementary school : Public } \cdot \text { Private } \\
\text { Former high school: Public } \cdot \text { Private } \\
\text { Junior high school : Public } \cdot \text { Private }\end{array}$ & \\
\hline 5. & $\begin{array}{l}\text { I started studying English: } \\
\text { Before elementary school }( \\
\text { in elementary school ( } \\
\text { in junior high school ( } \\
\text { outside of school ( }\end{array}$ & \\
\hline 6. & Overseas Travel: Place/Period ( & \\
\hline 7. & Native language: Japanese English Chinese Others ( & \\
\hline 8. & $\begin{array}{l}\text { What affects your beliefs about learning English? Tick and write details. } \\
\text { Studying at school ( ) } \\
\text { Advice from teachers / parents / brothers / sisters ( } \\
\text { Grades ( } \\
\text { of school ( } \\
\text { Knowledge outside of school ( ) } \\
\text { Personality ( }\end{array}$ & Experience outside \\
\hline 9. & What you think about learning English/English education? & \\
\hline 10. & What do you expect from teachers? & \\
\hline 11. & What are your beliefs about learning English? (e.g., accurate pronunciation is important) & \\
\hline 12. & What foreign language did you choose to study and why? & \\
\hline
\end{tabular}

\section{Appendix B: Interview protocol (English version)}

Theme: Students' beliefs about learning English

Time of interview:

Date:

Place:

Interviewee:

1. How do you describe your experiences of learning English?

2. How have your experiences influenced your beliefs about learning English?

3. Who has influenced your ideas and beliefs about learning English?

4. What are some of your successful/unsuccessful experiences of learning English?

5. When did (do) you feel a desire to learn English?

Thank you for your cooperation. 